\title{
Drug User
}

National Cancer Institute

\section{Source}

National Cancer Institute. Drug User. NCI Thesaurus. Code C84366.

A person who takes recreational drugs. 